ART BEYOND ITSELF 



\section{Art beyond Itself}

Anthropology for a Society without a Story Line

\section{NÉSTOR GARCÍA CANCLINI}

Translated by David Frye

DUKE UNIVERSITY PRESS

DURHAM AND LONDON 2014 
(C) 2014 Duke University Press

All rights reserved

Printed in the United States of America on acid-free paper $\infty$

Typeset in Whitman by Copperline Book Services, Inc.

Library of Congress Cataloging-in-Publication Data

García Canclini, Néstor.

[Sociedad sin relato. English]

Art beyond itself : anthropology for a society without a story

line / Néstor García Canclini ; translated by David Frye.

pages $\mathrm{cm}$

Includes index and references.

ISBN 978-0-8223-5609-7 (cloth : alk. paper)

ISBN 978-o-8223-5623-3 (pbk. : alk. paper)

1. Art and society.

2. Art and anthropology.

3. Postmodernism.

4. Aesthetics, Modern-21st century.

I. Frye, David L. II. Title.

N72.s6G372132014

701'.03-dc23 2013042792

Originally published as La sociedad sin relato: Antropología y estética de la inminencia, copyright 2010, Néstor García

Canclini. Spanish edition published by Katz Editores,

Buenos Aires and Madrid, 2010.

Duke University Press gratefully acknowledges the support of the Globalization and the Artist Project of the Duke University

Center for International Studies, which provided funds toward the production of this book. 
FOR MAGALI 
